\title{
Değer İnanç Norm Teorisi Temelinde Çevresel Duyarlılık Davranışlarının Ölçümü*
}

Measuring Environmentally Sensitive Behavior of Hospitality Managers in Slow Cities on the Basis of the Value Belief Norm Theory

\author{
Feriyal FARHADi ANDARABi**, Azize HASSAN*** \\ **(Sorumlu Yazar) Doktora Öğrencisi, Gazi Üniversitesi Sosyal Bilimler Enstitüsü, 06500 Emniyet Yenimahalle, Ankara. \\ E- Posta: feriyalfarhadi@hotmail.com \\ ORCID: 0000-0001-6425-6038 \\ *** Prof. Dr., Ankara Hacı Bayram Veli Üniversitesi Turizm Fakültesi, 06830 Gölbaşı, Ankara. \\ E- Posta: azize.hassan@hbv.edu.tr \\ ORCID: 0000-0003-2509-1415
}

MAKALE BILGILERI

Makale işlem bilgileri:

Gönderilme tarihi: 26 Kasım 2020

Birinci düzeltme: 29 Eylül 2021

İkinci düzeltme: 28 Ekim 2021

Kabul: 16 Kasım 2021

Anahtar sözcükler: Değer-inanç-norm teorisi, Yavaş şehir, Konaklama işletme sektörü, Çevresel duyarlılık davranışı.

\section{ARTICLE INFO}

Article history:

Submitted: 26 November 2020 Resubmitted: 29 September 2021

Resubmitted: 28 October 2021

Accepted: 16 November 2021

Key words: Value-belief-norm theory, Cittaslow, Hospitality management industry, Environmentally responsible behavior.

\begin{abstract}
ÖZ
Uluslararası Yavaş Şehir Birliği Bilim Kurulu, iklim değişikliğine ve çevresel sorunların çözülmesine ilişkin hassasiyetini, sunduğu üyelik kriterleri kapsamında bildirmiştir. Bu doğrultuda Türkiye'nin yavaş şehirlerindeki konaklama işletmesi yöneticilerinin işyerinde çevresel duyarlıık davranışları hakkında bilgi edinmek amaçlanmıştır. Araştırma amacına ulaşılması için Değer İnanç Norm Teorisi'nden (DiN) yararlanılmıştır. Basit tesadüfî yöntemle 18 yavaș șehirdeki üst ve orta kademe yöneticilerden 265 anket toplanmıștır. Verilerin analizinde LISREL ve SPSS paket programlarından yararlanılmıştır. Doğrulayıcı faktör analizi sonuçlarına göre bu örneklemde hesaplanan uygunluk değerlerinin kabul edilebilir aralıklar içerisinde olduğu görülmüştür. Değişkenler arasında bulunan korelasyon katsayıları ve faktör maddelerinin arasında regresyon ağırıklarının kabul edilebilir değerler kapsamında yer aldığı saptanmıştır. Araştırmanın nedensel zincirinde çevresel sorunların farkındalığıyla, atfedilen sorumlulukları üstlenmeye hazır olma arasındaki korelasyon katsayısı en düşük değeri temsil etmiştir. Çevresel norm ile çevresel duyarılıık davranışları arasında da zayıf ilişki bulunmuştur. Bireylerin proaktif çevresel duyarlılık davranışlarının motive edilmesinde sosyal psikoloji faktörlerinin dikkate alınması gerektiği, bu araştırmanın sonuçlarıyla desteklenmiştir.
\end{abstract}

\footnotetext{
* Bu çalışma, Gazi Üniversitesi Sosyal Bilimler Enstitüsü Turizm İşletmeciliği Dalında, Prof. Dr. Azize Hassan danışmanlığında yazılan, "Yavaş Şehirlerdeki Konaklama İşletmesi Personelinin Çevresel Duyarlılık Davranışlarının Değer İnanç Norm Teorisi Temelinde Ölçümü" başlıklı doktora tezinden üretilmiştir.
}

\begin{abstract}
The International Cittaslow Scientific Committee has announced their concerns regarding climate change and solution of environmental issues within the scope of their membership criteria. Accordingly, it was aimed to gather information about environmental awareness behaviors of hotel managers in slow cities in Turkey. Value-Belief-Norm (VBN) Theory had been used to achieve the objectives of this study. 265 questionnaires were collected from top and mid-level hotel executives from 18 slow cities via simple random sampling method. LISREL and SPSS package programs were used for data analysis. According to the results of confirmatory factor analysis, it was found that the conformity values calculated in this sample were within acceptable ranges. It was also found that the regression weights between the correlation coefficients and the factor items found among the variables were within the acceptable ranges of value. Within the causal chain of this research, the correlation coefficient between the awareness of environmental issues and the readiness for undertaking assigned responsibilities represented the minimum value. A weak relationship was found between environmental norm and environmental awareness behaviors. The results of this study supported the fact that the socio-psychological factors in motivation of individuals' proactive environmental awareness behaviors should be taken into consideration.
\end{abstract}

\section{GiRiş}

İnsanın hayatta kalabilmek için verdiği ilkel mücadeleler, zaman içinde yerini sosyoekonomik açıdan daha konforlu ve kaliteli bir yaşam istemi- 
ne bırakmıştır. Her ne kadar mücadele biçiminde farklı yöntemlerin kullanıldığı görülse de planlanan amaçlara ulaşma gayesi, doğayı ve çevreyi olumlu veya olumsuz şekilde etkilemektedir. Söz konusu olumsuz etkilerin farkına varan Birleşmiş Milletler, 2012 yılında sürdürülebilir kalkınma hedeflerine ulaşmak için Donut Ekonomi Modeli'ni önermiştir (O'Neill vd. 2018). Ancak daha önce, 2009 yılında Yavaş Şehir Birliği, çevreyi ve sosyoekonomik refah düzeyini göz önünde tutarak sürdürülebilir şehir yönetim anlayışını ileri sürmüştür. Birlik, küçük şehirlerde ve kasabalarda ekonomik ve sosyal açıdan sürdürülebilirliği planlarken çevre kirliliğini önlemek ve doğayı korumak için üyelik kriterlerinde bireyleri, yerel yönetimleri ve yerel işletmeleri sorumluluklarını üstlenmekle yükümlü kılmıştır (Cittaslow International 2020).

Yavaş şehirlerde bulunan konaklama işletmelerinin de Birliğin belirlediği kriterlere uyum sağlaması gerekmektedir. Bunun için yöneticilerin ve işgörenlerin çevreye duyarlı davranışlara eğilimli olmaları önemlidir. Nitekim Choi vd. (2019), konaklama işletmelerindeki yöneticilerin, çevre sorunlarını yorumlamada ve işyerinde çevreye duyarlı davranışların uygulanmasında önemli rollerinin olduğunu vurgulamışlardır.

İnsan ve çevre arasındaki ilişki karşılıklı etkileşim şeklindedir (Stern 2000). Bu nedenle, bireylerin çevresel duyarlılık davranışlarının araştırılmasında, özellikle son dönemlerde DİN Teorisi tercih edilmektedir (Han vd. 2018). Bu araştırmada, 18 yavaş şehirde faaliyet gösteren konaklama işletmelerinde, üst ve orta kademe yöneticilerin çevresel duyarlılık davranışlarının öngörülmesi için DİN Teorisi'nden faydalanılmıştır. Katılımc1ların, anket formunda yer alan sorulara tarafsız ve dikkatli bir biçimde yanıt verdikleri varsayılmıştır. Alanyazın taramasında, konaklama işletmeleri yöneticilerinin, çevre yönetimi ve uygulamalarına ilişkin bakış açılarını inceleyen araştırmaların mevcut olduğu görülmektedir (Bohdanowicz ve Zientara 2014). Ayrıca yöneticilerin, çevre etiketli konaklama işletmelerinin önemli unsurlarına dair değerlendirmelerini inceleyen araştırmalar da bulunmaktadır (Kim vd. 2017). Ancak konaklama işletmelerinde yöneticilerin çevresel duyarlılık davranışlarını DİN Teorisi temelinde ölçen araştırmaya rastlanmamıştır. Ayrıca örneklemlerin ilk kez bu araştırmada yavaş şehirlerden seçilmiş olması araştırmayı özgün kılmaktadır.

\section{KURAMSAL ÇERÇEVE}

Sosyal psikoloji alanyazınında, sosyal grupları oluşturan bireylerin çevresel duyarlılık davranışlarının, kendilerine özgü nitelikleri ve değerleriyle bağlantılı olarak farklılık gösterdiği kanıtlanmıştır (Stern 2000). Schwartz'ın Temel Değer Teorisi'ni (TD) esas alarak, bireylerin çevresel duyarlılık davranışlarını öngörmeye çalışan Stern vd., beş değişkenden oluşan bir nedensel zincir kurgulamışlardır. Bu nedensel zincirin ilk aşamasında bireyin egoistik, alturistik ve biyosferik değer yargılarından etkilenen bireysel değerlerinin, yeni ekolojik dünya görüşüne yansıdığı ve zincirin devamında çevresel duyarlılık inancını ve normunu tetiklediği varsayılmıştır (Stern vd. 1999; Stern 2000).

DINN Teorisi'ne göre, paraya ve güce önem veren egoistik kişilikli birey, kendi çıkarları dışında diğer varlıkları pek önemsememektedir. Bireyin egoistik değer yargısının baskınlığı arttıkça, çevresel sorunların en aza indirilmesi veya çözülmesi için gösterdiği duyarlılık düzeyi azalmaktadır (Van der Werff ve Steg 2016). Bu nedenle araştırmanın H1 hipotezinde, yöneticilerin bireysel egoistik değer yargılarıyla değerleri arasında negatif ilişki olduğu varsayılmıştır.

DİN Teorisi'nde, bireyin biyosferik ve alturistik değer yargılarının artması olumlu bir durum olarak değerlendirilir. Bu iki değer yargısı, bireysel değeri tetiklemekte ve çevresel risklere yönelik duyarlılığı etkilemektedir (Dietz vd. 2005). Buradan, katılımciların bireysel alturistik ve biyosferik değer yargıları ile bireysel değerleri arasında olumlu ilişki olduğu varsayılarak H2 ve H3 hipotezleri kurulmuştur.

DİN Teorisi'nde, bireyin çevresel sorunlardan kaynaklanan zararlarla ilgili inancı hakkında önbilgiye ulaşmak için nedensel zincirde bireysel değer değişkeni çevresel duyarlılık inanç değişkenine bağlanmış ve aralarındaki ilişki düzeyi önemsenmiştir. Bireyin yeni ekolojik dünya gö- 
rüşü, çevresel sorunların farkındalığı ve atfedilen sorumlulukları üstlenmeye hazır olma boyutları, İnançlar başlığı altında sorgulanmıştır (Stern vd. 1999).

Yeni ekolojik dünya görüşünde birey, çevresel sorunların kendine, başkalarına ve dünyaya verdiği zararlara ilişkin düşüncelerini beş boyutta ortaya koymaktadır. Burada temel amaç, insanlığın doğaya ve varlıklarına yaklaşım biçimini ve bunları korumaya yönelik düşünce yapısını anlayabilmektir (Dunlap vd. 2000). Araştırmada, katılımcıların bireysel değerleri ile yeni ekolojik dünya görüşleri arasında ilişki olduğu varsayılmış ve $\mathrm{H} 4$ hipotezinin doğruluk payı sınanmıştır.

Nedensel zincirin inançlar başlığı altındaki ikinci basamağında, bireyin çevre sorunlarına ilişkin farkındalığı sorgulanmaktadır. Buradaki asıl amaç, bireyde konuya ilişkin farkındalık mekanizmasının gücünü belirlemektir. DİN Teorisi'nde söz konusu mekanizmanın motive edilmesinde, bireyin genel inancını açılayan yeni ekolojik dünya görüşünün etkisi olduğu varsayılmıştır (Stern vd. 1999). Buradan, katılımcıların yeni ekolojik dünya görüşleri ile çevresel sorunların farkındalığı arasında olumlu ilişki olduğu kabul edilmiş ve H5 hipotezi geliştirilmiştir.

Schwartz'a (1977) göre bireyin özgecil davranışı, bir durumun başkalarına zarar verebileceğinin farkında olmasıyla gerçekleşmektedir. Stern (2000), toplumların çevresel duyarlılık davranışlarının kavranması ve değiştirmeye yönelik stratejiler geliştirilmesi için inanç boyutlarına ve motivasyon faktörlerine odaklanılmasını önermektedir. Birey, kendisinde çevre sorunlarıyla ilgili sorumluluk hissi uyandığında ve bu konuda güçlü inanç oluştuğunda etkili çevresel duyarlılık davranışlarında bulunabilir. Dolayısıyla H6 hipotezinde, katılımcıların çevresel sorunların farkındalığı ile atfedilen çevresel sorumlulukları üstlenmeye hazır olma değișkenleri arasında olumlu ilişki olduğu varsayılmıştır.

Bireyde çevresel duyarlılık inancı oluştuğunda ahlaki zorunluluk duygusu harekete geçmektedir. Alturistik değer yargısının da etkisiyle bireyin inancı çerçevesinde oluşan bu duygu, çevresel duyarlılık normlarını motive etmektedir. Norm Aktivasyon Teorisi de bu düşünceye da- yanılarak kurulmuş ve başkalarına, size yapılmasını istediğiniz gibi davranın mesajını barındırmaktadır. DİN Teorisi'nde bireyin, atfedilen sorumlulukları üstlenmeye hazır olma duygusuyla çevresel duyarlılık normları arasındaki ilişki düzeyinin yüksek çıkması durumu olumlu karşılanır (Stern ve Dietz 1994). Bu araştırmada, bu iki değişken arasında pozitif ilişki olduğu varsayılarak $\mathrm{H} 7$ hipotezi geliştirilmiştir.

DİN Teorisi'ndeki nedensel zincir, istikrarlı kişilik ve çevresel duyarlılık inancının yüksek olduğu varsayımıyla oluşturulmuştur. Teori ile, insan-çevre ilişkisinin ilkelerine dayalı değer yargılarından yola çıkılarak çevresel tehditler ve eylem sorumluluğu üzerine odaklanmış inançlara doğru hareket eden bireyde, ahlaki yükümlülük duygusuyla çevresel duyarlılık davranışlarının öngörülmesi planlanmıştır (Stern vd. 1999). Bu nedenle $\mathrm{H} 8$ hipotezinde, katılımcların bireysel çevresel normları ile bireysel çevresel davranışları arasında olumlu ilişki olduğu varsayılmış ve doğruluk payı aranmıştır.

Turizm alanyazınında, bireylerin çevresel duyarlılık davranışlarının öngörülmesi için DİN Teorisi'ne uyarlanan araştırmalara rastlanmaktadır. Bu araştırmalarda genellikle yapısal eşitlik modellemesinin kullanıldığı saptanmıştır. Ayrıca bireylerin biyosferik değer yargıları, çevresel duyarlılık inançları ve normlarının, çevresel duyarlılık davranışları üzerinde olumlu etkisi olduğu kanıtlanmıştır (Choi vd. 2015; Han vd. 2018).

Turizm alanında yapılan bazı araştırmalarda ise bireylerin çevresel duyarlılık davranışlarının öngörülmesi için DİN Teorisi'yle başka teorilerin entegre edildiği tespit edilmiştir. Han (2015), DIN ve Planlı Davranış teorilerinden faydalanarak bireylerin çevresel duyarlılık davranışlarını ölçüp yeni bir model önerisinde bulunmuştur. Birleşik modellemeyle, daha iyi sonuç alındığ 1 bildirilmiştir. Olya ve Akhshik'in (2019) araştırmasında da bu iki teori entegre edilmiş ancak yöntemsel açıdan farklı olarak verilerin analizinde Yapısal Eşitlik Modellemesi yerine fsQCA analizi kullanılmıştır. Kültürel değer yargısı boyutunu DİN Teorisi içinde ilk kez Megeirhi vd. (2020), kültürel mirasa sahip ve turizmin yoğun olduğu bir destinasyonda yerel halkın koruyucu 
davranışlarını ölçmek için kullanmışlardır. Söz konusu araştırmada ulaşılan, yerel halkın egoistik değer yargılarının kültürel değer yargılarına baskın olması sonucu dikkat çekicidir. DİN Teorisi temelinde yapılan önceki araştırmalarda, müze ve destinasyon ziyaretçileri ile yerel halkın çevresel duyarlılık davranışları ölçülmüştür. Bu araştırmada farklı olarak ilk kez konaklama işletmesi yöneticilerinin bireysel değerleri, inançları ve normları DİN Teorisi temelinde incelenerek alanyazındaki boşluğun doldurulması amaçlanmıştır.

\section{YÖNTEM}

Araştırmada nicel yöntem kullanılmış ve veriler anket aracılığıyla toplanmıştır. Araştırma anketinde değer, yeni ekolojik dünya görüşü, çevresel sorunların farkındalığı, atfedilen çevresel sorumlulukların üstlenilmesi ve norm ölçekleri kullanılmıştır. Yöneticilerin bireysel değer yarg1larının ölçülmesi için Stern ve Dietz'in (1994: 77) 13 maddelik ölçeği kullanılmıştır. 15 maddelik yeni ekolojik dünya görüşü ölçeği Dunlap vd.nin (2000: 433) çalışmasından alınmıştır. Çevresel sorunların farkındalığının ölçülmesi için Stern vd.nin (1993: 333) dokuz maddelik ölçeğinden faydalanılmıştır. Yöneticilerin atfedilen sorumlulukları üstlenmeye hazır olma duygularının belirlenmesi için Steg vd. (2005: 419) tarafından oluşturulmuş altı maddelik ölçek kullanılmıştır. Yöneticilerin bireysel çevresel normlarının açıklanması için Choi vd.nin (2015: 93) 10 maddelik ölçeğinden yararlanılmıştır. Bireysel değer yargıları ölçeğinde bulunan 13 maddenin cevaplanmasında; Benim ilkelerime terstir=-1, Benim için önemli değildir $=0$, Benim için önemi çok azdır $=1$, Benim için önemi azdır=2, Benim için orta düzeyde önemlidir=3, Benim için önemlidir $=4$, benim için kesinlikle önemlidir=5 seçenekleri kullanılmıştır (Stern ve Dietz 1994). Araştırma anketinde yer alan diğer ölçeklerin tamamında cevap seçenekleri beşli Likert; Kesinlikle katılmıyorum=1, Katılmıyorum=2, Orta düzeyde katılıyorum=3, Katılıyorum=4, Kesinlikle katılıyorum=5 şeklinde hazırlanmıştır.

Gazi Üniversitesi Etik Komisyonu tarafından 10.02.2018 tarihinde oybirliğiyle kabul edilen ve araştırmanın uygulanmasında sakınca olmadı̆̆1nın belirtildiği E.24847 sayı ve 2018-28 araştırma kod numaralı belgeye dayanılarak verilerin toplanması planlanan yavaş şehirlerdeki belediye başkanlarıyla veya yavaş şehir koordinatörleriyle iletişime geçilmiş ve anketin uygulanması için ilgili makamlardan gereken izinler alınmıştır. 85 katılımcıdan oluşan üst ve orta kademeli konaklama işletmesi yöneticileriyle gerçekleşen pilot anket çalışmasından elde edilen veriler analiz edilmiş ve Cronbach Alpha katsayılarına bakılmıştır. Bu çerçevede, yöneticilerin bireysel değerleri $(0,825)$, yeni ekolojik dünya görüşleri $(0,863)$, çevresel sorunlara karşı farkındalıkları $(0,811)$, atfedilen sorumlulukları üstlenmeye hazır olmaları $(0,815)$ ve çevresel normları $(0,874)$ güvenirlik puanları açısından analiz edilmiş ve Cronbach Alpha değerleri kabul edilir aralıklarda bulunmuştur. Bu sonuç doğrultusunda asıl araştırma anketinin uygulanma süreci başlatılmıştır.

Araştırmanın yapıldığ 1 dönemde, Türkiye'nin 18 yavaş şehrinde, belediye ve T.C. Kültür ve Turizm Bakanlığı'ndan işletme ruhsatına sahip 288 konaklama işletmesinin faaliyette bulunduğu belirlenmiştir. Bu araştırmada doğru bilgilere ulaşmak için evren büyüklüğünden çekilmesi gereken örneklem büyüklüğünün, $\alpha=0,05$ hata payıyla 165 kişi yeterli bulunmuştur (Büyüköztürk vd.nin 2011). Basit tesadüfî yöntemle 18 yavaş şehirdeki üst ve orta kademeli konaklama işletmesi yöneticileriyle yapılan yüz yüze görüşmelerden 265 anket toplanmıştır. Toplanan 265 anketin verileri LISREL 8.51 ve IBM SPSS 20.0 paket programlarıyla analiz edilmiştir. Yapısal eşitlik modellemesi çerçevesinde doğrulayıcı faktör analizleri yapılmış ve ki-kare/sd, RMSEA, GFI, AGFI, NFI, CFI ve TLI uyum değerlerine bakılmıştır. Bununla birlikte korelasyon ve regresyon analizlerinden faydalanılmıştır. Araştırmada analizler için elde edilen sonuçlar 0,01 ve 0,05 anlamlılık düzeyinde yorumlanmıştır.

\section{BULGULAR}

Katılımcıların yaş, cinsiyet, eğitim durumlarıyla ilgili bilgiler esas alınmıştır. Ayrıca küçük aile işletmesi (en fazla 15 odalı), büyük aile işletmesi (15 oda üstü) veya aile işletmesi değildir seçenek- 
leri sunularak katılımclardan hangi işletme türünde çalıştıklarını belirtmeleri istenmiştir. Katılımcıların yüzde 59'u küçük aile işletmesi, yüzde $23^{\prime}$ ü aile işletmesi değildir ve yüzde $18^{\prime}$ i büyük aile işletmesi yanıtını vermiştir. Bu verilerden, Türkiye' nin yavaş şehirlerindeki konaklama işletmelerinin çoğunun aile işletmesinden oluştuğu sonucu çıkarılabilir. Yapılan yüz yüze görüşmelerde işletmelerin çoğunun, baba ve erkek çocuklar tarafından yönetildiği bilgisi edinilmiştir.

Yaş profili açısından, katılımcıların yüzde 35'i 46 yaş ve üzerinde; yüzde 24'ü 31-35; yüzde 21'i 36-40 yaş aralığındadır. Cinsiyet profili açısından katılımcıların yüzde 66'sı erkek ve yüzde 34'ü kadındır. Eğitim durumu açısından katılımciların yüzde 50'si üniversite mezunu, yüzde 42 'si lise ve yüzde 8'i ilköğretim okulu mezunudur. Katılımcıların çoğunlukla eğitimli oldukları görülmektedir.

Tablo 1'de görüldüğü üzere katılımcıların bireysel değer yargılarına ilişkin yanıtlar, 3,28 toplam ortalama puana sahiptir $(\mathrm{p}<0,05)$. Biyosferik değer yargıları 3,82 ve alturistik değer yargıları 3,81 ortalamayla istatistiksel anlamda orta düzeyde puanları yansıtmaktadır. Egoistik değer yargisı boyutuna ait 2,44 ortalama puan, katılımcıların az da olsa egolu bir kişilik yapısına sahip olduklarını açıklamaktadır. Dikkate alınması gereken şu ki DİN Teorisi, bireylerin psikososyal özellikleri temel alınarak kurulmuş olup, egoistik değer yargılarından tamamen arınan ve yeryüzünde tüm varlıklara yönelik olarak yüksek düzeyde fedakârlık hissi besleyen bireyin çevreye duyarlı davranışlarda bulunabileceğini savunmaktadır (Dietz 2020).

Tablo 2'de görüldüğü gibi insan egemenliği boyutunda, hayvanlar ve bitkilerin de en az insanlar kadar yaşama hakları vardır maddesi 4,17 ortalama puanla öne çıkmaktadır. Ardından, 4,02 ortalama puana sahip olan, insan, zekâ gibi çok özel yeteneklere sahip olsa bile yine de doğa kanunlarına tabidir maddesi katılımcıların insan merkezli düşüncelerinin baskın olmadığını göstermektedir. Genel olarak yeni ekolojik dünya görüşlerini belirleyen 15 maddenin toplam ortalama puanı $(\bar{x}=3,48$ ve $p<0,05)$, katılımciların, doğaya salt bir değer biçtiklerini ve kendi çıkarları doğrultusunda doğayı hoyratça kullanmayacak bireyler olduklarını göstermektedir.

DİN Teorisi'yle bireyin çevre sorunlarına ilişkin farkındalık düzeyinin belirlenmesinde değer yargılarından destek alınmaktadır. Tablo 3'te görüldügü gibi katılımcıların alturistik değer yargılarının olumlu etkisi çevresel sorunlara yönelik farkındalığın artmasını $(\bar{x}=4,43)$ sağlamaktadır. Bununla birlikte katılımcıların yüksek biyosferik değer yargılarının, farkındalıklarına olumlu yan-

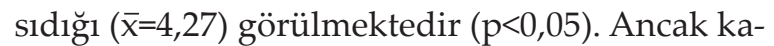
tılımcıların toplam ortalama egoistik değer yargıları puanının nispeten yüksek çıkması $(\bar{x}=4,43)$ çevresel sorunlara yönelik farkındalıkları üzerinde olumsuz etki bıraktığı anlamina gelmektedir. Han (2015), Landon vd. (2018) araştırmalarında, bireylerin değer yargılarının yeni ekolojik dünya görüşlerine ve bunun da çevresel sorunların farkındalık düzeyine yansıdı ğını ve aralarında mantıksal ilişki bulunduğunu vurgulamışlar ve bu araştırmada da benzer sonuçlar bulunmuştur. Ancak söz konusu araştırmalarda çevresel sorunların farkındalığı ölçeğine ait alt değerler irdelenmemiştir.

Katılımcılardan alınan yanıtlara göre şu aşamaya kadar çevresel sorunların farkında olduklarına dair belirtiler saptansa da Tablo 4 incelendiğinde atfedilen çevresel sorumlulukları üstlenmedikleri tespit edilmiştir $(\bar{x}=2,81$ ve $\mathrm{p}<0,05)$. Chaney ve Martin (2017), bireyin çevresel duyarlılık davranışlarında bulunması için atfedilen sorumlulukları üstlenmeye hazır olma aşamasına gelmesinin önemini ortaya koymuşlar ve bu boyutun bireyin değer yargılarından etkilendiği çıkarımında bulunmuşlardır.

Tablo 5'te, katılımcıların, orta düzeyde çevresel duyarlılık normlarına sahip oldukları $(\bar{x}=3,18$ ve $\mathrm{p}<0,05)$ görülmektedir. Schwartz (1977), bireysel normların davranışlar üzerindeki etkisinin, dişsal ve geçici motivasyon sağlayan ödüllerden veya cezalardan çok daha güçlü olduğunu bildirmiştir. Van Der Linden (2015), çevresel duyarlılık davranışlarının, kısa vadeli ödüller değil, bireylerin sahip oldukları normlar üzerinden oluştuğunu kanitlamıştır.

DİN Teorisi'nin bu örnekleme uyarlanması ve araştırma hipotezlerinin sınanması için uyum 
Değer İnanç Norm Teorisi Temelinde Çevresel Duyarlılık Davranışlarının Öıçümü

Tablo 1. Katılımcıların Egoistik, Alturistik ve Biyosferik Değer Yargılarının Puanları (n=265)

\begin{tabular}{|c|c|c|c|c|c|c|c|}
\hline Boyut & Madde & $\begin{array}{l}\text { Faktör } \\
\text { Yükü }\end{array}$ & Ortalama & SS & Ortalama & $\begin{array}{l}\text { Cronbach } \\
\text { Alfa }\end{array}$ & Özdeğer \\
\hline \multirow{5}{*}{ Egoistik } & $\begin{array}{l}\text { Hayatımda yetki temel ilkemdir (örneğin, } \\
\text { liderlik veya komuta etme hakkı). }\end{array}$ & 0,845 & 2,61 & 1,76 & \multirow{5}{*}{2,44} & \multirow{5}{*}{0,818} & \multirow{5}{*}{3,456} \\
\hline & $\begin{array}{l}\text { Hayatımda sosyal güç temel ilkemdir } \\
\text { (örneğin, başkaları üzerinde kontrol sahibi } \\
\text { olmak, egemenlik kurmak). }\end{array}$ & 0,879 & 2,54 & 1,62 & & & \\
\hline & $\begin{array}{l}\text { Hayatımda servet temel ilkemdir (örneğin, } \\
\text { para veya mal edinmek). }\end{array}$ & 0,864 & 2,07 & 1,66 & & & \\
\hline & $\begin{array}{l}\text { Hayatımda etki temel ilkemdir (örneğin, } \\
\text { kişiler ve olaylar üzerinde etkili ve nüfuzlu } \\
\text { olmak.) }\end{array}$ & 0,840 & 2,66 & 1,62 & & & \\
\hline & $\begin{array}{l}\text { Hayatımda hırs temel ilkemdir (örneğin, } \\
\text { ihtiraslı olmak). }\end{array}$ & 0,855 & 2,30 & 1,76 & & & \\
\hline \multirow{4}{*}{ Alturistik } & $\begin{array}{l}\text { Hayatımda sosyal adalet temel ilkemdir } \\
\text { (örneğin, adaletsizliğe karşı durmak, } \\
\text { mağdurun ve zayıfın yanında yer almak) }\end{array}$ & 0,877 & 3,71 & 1,42 & \multirow{4}{*}{3,81} & \multirow{4}{*}{0,850} & \multirow{4}{*}{2,698} \\
\hline & $\begin{array}{l}\text { Hayatımda faydalı olmak temel ilkemdir } \\
\text { (örneğin, başkalarının refahı için çalışmak, } \\
\text { yararlı olmak). }\end{array}$ & 0,873 & 3,76 & 1,31 & & & \\
\hline & $\begin{array}{l}\text { Hayatımda eşitlik temel ilkemdir (örneğin, } \\
\text { herkes için eşit fırsat sağlamak). }\end{array}$ & 0,862 & 3,83 & 1,35 & & & \\
\hline & $\begin{array}{l}\text { Hayatımda barış içinde bir dünya istemek } \\
\text { temel ilkemdir. }\end{array}$ & 0,871 & 3,94 & 1,24 & & & \\
\hline \multirow{4}{*}{ Biosferik } & $\begin{array}{l}\text { Hayatımda çevrenin korunması temel } \\
\text { ilkemdir. }\end{array}$ & 0,867 & 3,94 & 1,32 & \multirow{4}{*}{3,82} & \multirow{4}{*}{0,825} & \multirow{4}{*}{1,634} \\
\hline & $\begin{array}{l}\text { Hayatımda kirliliğin önlenmesi temel } \\
\text { ilkemdir (örneğin, çevre dostu enerjileri } \\
\text { kullanmak). }\end{array}$ & 0,886 & 3,82 & 1,39 & & & \\
\hline & $\begin{array}{l}\text { Hayatımda dünya ve varlıklarına saygı } \\
\text { göstermek temel ilkemdir (örneğin, } \\
\text { dünyanın diğer türleri ile uyumlu yaşamak). }\end{array}$ & 0,890 & 3,66 & 1,49 & & & \\
\hline & $\begin{array}{l}\text { Hayatımda doğayla uyumlu ve iç içe } \\
\text { yaşamak temel ilkemdir. }\end{array}$ & 0,870 & 3,88 & 1,31 & & & \\
\hline
\end{tabular}

Toplam ortalama: 3,28

Toplam Açıklanan Varyans: \%64

ölçütlerine bakılmıştır. Hesaplanan ölçüt değerlerinin $\left(\chi^{2} / \mathrm{sd}=2,198\right.$, RMSEA $=0,055$, GFI $=0,905$, $\mathrm{NFI}=0,904$, AGFI $=0,876, \mathrm{CFI}=0,908$, TLI $=0,900$, $\mathrm{p}<0,001)$ kabul edilebilir aralıklarda olduğu bulunmuştur (Browne ve Cudeck 1993).

Bu araştırmada, DIN Teorisi'nin nedensel zincirinde yer alan değişkenler arasında ilişki olup olmadığını ve varsa gücünü belirlemek için yol analizi yapılmıştır. Katılımcıların değerlerinden yola çıkılarak gözlenen ve gizil değişkenler arasındaki korelasyon katsayıları hesaplanmıştır. Bireysel değerler gizil değişkeni ile egoistik değer yargısı arasındaki ilişki katsayısı $(\mathrm{r}=0,11$; $\beta=0,14 ; P=0,420>0,05$ ) istatistiksel olarak önemsiz bulunmuştur. Bu sonuç Landon vd.nin (2018) araştırmalarıyla benzerlik göstermektedir. 
Tablo 2. Katılımcıların Yeni Ekolojik Dünya Görüşü Puanları (n=265)

\begin{tabular}{|c|c|c|c|c|c|c|c|}
\hline Boyut & Madde & $\begin{array}{l}\text { Faktör } \\
\text { Yükü }\end{array}$ & Ortalama & SS & Ortalama & $\begin{array}{c}\text { Cronbac } \\
\text { h Alfa }\end{array}$ & Özdeğer \\
\hline \multirow{3}{*}{$\begin{array}{l}\text { Büyüme } \\
\text { sınırlarının } \\
\text { gerçeği }\end{array}$} & $\begin{array}{l}\text { Dünyanın besleyebileceği insan sayısında } \\
\text { sınıra yaklaşıyoruz. }\end{array}$ & 0,822 & 3,64 & 1,13 & \multirow{3}{*}{3,37} & \multirow{3}{*}{0,791} & \multirow{3}{*}{5,231} \\
\hline & $\begin{array}{l}\text { Dünyanın doğal kaynakları sınırsızdır; yeter ki } \\
\text { o kaynakları geliştirmeyi öğrenelim. }\end{array}$ & 0,820 & 3,16 & 1,37 & & & \\
\hline & $\begin{array}{l}\text { Dünya, çok sınırlı sayıda odası ve kaynağı olan } \\
\text { bir uzay gemisi gibidir. }\end{array}$ & 0,826 & 3,32 & 1,26 & & & \\
\hline \multirow{3}{*}{$\begin{array}{l}\text { İnsan } \\
\text { egemenliği }\end{array}$} & $\begin{array}{l}\text { İnsanın doğal çevreyi kendi ihtiyaçlarına göre } \\
\text { değiştirme hakkı yoktur. }\end{array}$ & 0,824 & 3,93 & 1,12 & \multirow{3}{*}{3,46} & \multirow{3}{*}{0,801} & \multirow{3}{*}{4,201} \\
\hline & $\begin{array}{l}\text { Hayvanlar ve bitkiler de en az insanlar kadar } \\
\text { yaşama hakkına sahiptirler. }\end{array}$ & 0,857 & 4,17 & 0,99 & & & \\
\hline & İnsanoğlu doğaya hükmetme hakkına sahiptir. & 0,858 & 2,27 & 1,27 & & & \\
\hline \multirow{3}{*}{$\begin{array}{l}\text { Doğa } \\
\text { dengesinin } \\
\text { kırılganlığı }\end{array}$} & $\begin{array}{l}\text { Insan doğaya müdahale ettiğinde sonuçlar } \\
\text { çoğu zaman felaket olur. }\end{array}$ & 0,842 & 3,92 & 0,98 & \multirow{3}{*}{3,47} & \multirow{3}{*}{0,785} & \multirow{3}{*}{3,206} \\
\hline & $\begin{array}{l}\text { Doğanın dengesi, modern sanayileşmiş } \\
\text { ulusların etkileriyle başa çıkabilecek kadar } \\
\text { güçlüdür. }\end{array}$ & 0,838 & 2,84 & 1,33 & & & \\
\hline & $\begin{array}{l}\text { Doğanın dengesi çok hassas olup kolayca } \\
\text { bozulabilir. }\end{array}$ & 0,836 & 3,65 & 1,19 & & & \\
\hline \multirow{3}{*}{$\begin{array}{l}\text { Muafiyetçiliğin } \\
\text { reddi }\end{array}$} & $\begin{array}{l}\text { İnsan, aklı ve yaratıcılığıyla her durumda } \\
\text { dünyayı yaşanabilir kılacaktır. }\end{array}$ & 0,844 & 3,26 & 1,29 & \multirow{3}{*}{3,59} & \multirow{3}{*}{0,798} & \multirow{3}{*}{1,998} \\
\hline & $\begin{array}{l}\text { İnsan, zekâ gibi çok özel yeteneklere sahip } \\
\text { olsa bile yine de doğa kanunlarına tabidir. }\end{array}$ & 0,880 & 4,02 & 0,92 & & & \\
\hline & $\begin{array}{l}\text { İnsan, doğayı kontrol etmeye yetecek bilgiyi } \\
\text { hiçbir zaman elde edemeyecektir. }\end{array}$ & 0,852 & 3,48 & 1,24 & & & \\
\hline \multirow{3}{*}{$\begin{array}{l}\text { Ekokriz } \\
\text { olasılığı }\end{array}$} & $\begin{array}{l}\text { İnsan, doğayı ve kaynaklarını ciddi derecede } \\
\text { istismar etmekte ve aşırı tüketmektedir. }\end{array}$ & 0,872 & 3,99 & 1,04 & \multirow{3}{*}{3,54} & \multirow{3}{*}{0,803} & \multirow{3}{*}{1,365} \\
\hline & $\begin{array}{l}\text { İnsanlığın karşı karşıya kaldı̆̆ı "ekolojik kriz" } \\
\text { denen olay çok fazla abartılmaktadır. }\end{array}$ & 0,868 & 2,44 & 1,28 & & & \\
\hline & $\begin{array}{l}\text { Her şey şu andaki seyri ile devam ederse } \\
\text { yakında büyük bir çevre felaketi yaşayacağız. }\end{array}$ & 0,875 & 3,98 & 1,03 & & & \\
\hline
\end{tabular}

Toplam Ortalama: 3,48

Toplam Açıklanan Varyans: $\% 64$

Egoistik değer yargisıyla bireysel değerlere giden yol katsayısı anlamsız bulunduğu için nedensel zincirde yer alan egoistik değer yargısının çıkartılmasına karar verilmiş ve uyum ölçütlerine tekrar bakılmıştır. Buradan, $\chi^{2} / \mathrm{sd}=2,120$, RMSEA $=0,051$ GFI $=0,913$, NFI $=0,925$, AGFI $=0,888$, $\mathrm{CFI}=0,917$ ve $\mathrm{TLI}=0,910, \mathrm{p}<0,001$ şeklinde bulunan uyum ölçütleri kabul edilir değerleri temsil etmektedir. Nedensel zincire ait standartlaştırılmış yol katsayıları Şekil 1'de görülmektedir.
Nedensel zincirden, katılımciların egoistik değer yargılarının çıkarılması $\mathrm{H}_{1}$ hipotezini geçersiz kılmıştır. Ancak katılımcıların alturistik $(r=0,85)$ ve biyosferik $(r=0,92)$ değer yargilarılya bireysel değerleri arasında pozitif yönde güçlü ilişkiler bulunmuştur. Dolayısıyla alturistik ve biyosferik değer yargılarının çevresel bağlamda bireysel değer sistemlerini olumlu yönde etkilediği söylenebilir. 
Değer İnanç Norm Teorisi Temelinde Çevresel Duyarlılık Davranışlarının Öıçümü

Tablo 3. Katılımcıların Çevresel Sorunların Farkındalığı Puanları (n=265)

\begin{tabular}{|c|c|c|c|c|c|c|c|}
\hline Boyut & Madde & Faktör Yükü & Ortalama & SS & Ortalama & $\begin{array}{l}\text { Cronbach } \\
\text { Alfa }\end{array}$ & Özdeğer \\
\hline \multirow[t]{3}{*}{$\mathrm{SF}_{\text {Ego }}$} & $\begin{array}{l}\text { Çevrenin korunması sağlığım için } \\
\text { faydalıdır. }\end{array}$ & 0,890 & 4,37 & 0,98 & \multirow{3}{*}{4,43} & \multirow{3}{*}{0,834} & \multirow{3}{*}{3,654} \\
\hline & $\begin{array}{l}\text { Çevrenin korunması ben ve } \\
\text { çocuklarım için daha iyi bir dünya } \\
\text { sağlar. }\end{array}$ & 0,885 & 4,47 & 0,82 & & & \\
\hline & $\begin{array}{l}\text { Çevrenin korunması hayat kalitemi } \\
\text { iyileştirir. }\end{array}$ & 0,882 & 4,47 & 0,81 & & & \\
\hline \multirow[t]{3}{*}{ SF } & $\begin{array}{l}\text { Çevrenin korunmasının hepimize } \\
\text { faydası var. }\end{array}$ & 0,874 & 4,53 & 0,70 & \multirow{3}{*}{4,43} & \multirow{3}{*}{0,812} & \multirow{3}{*}{2,424} \\
\hline & $\begin{array}{l}\text { Çevrenin korunması daha iyi bir } \\
\text { dünya demektir. }\end{array}$ & 0,865 & 4,45 & 0,80 & & & \\
\hline & $\begin{array}{l}\text { Neden olduğumuz çevresel sorunlar } \\
\text { insanları etkilemektedir. }\end{array}$ & 0,868 & 4,31 & 0,91 & & & \\
\hline \multirow[t]{3}{*}{$\mathrm{SF}_{\text {Bio }}$} & $\begin{array}{l}\text { Önümüzdeki on yıl içerisinde binlerce } \\
\text { bitki türü ve hayvan yok olma } \\
\text { tehlikesiyle karşı karşıya. }\end{array}$ & 0,830 & 4,18 & 0,96 & \multirow{3}{*}{4,27} & \multirow{3}{*}{0,805} & \multirow{3}{*}{1,398} \\
\hline & $\begin{array}{l}\text { İklim değişikliği hakkında söylenen } \\
\text { her şey abartıdan ibarettir. }\end{array}$ & 0,845 & 4,35 & 1,37 & & & \\
\hline & $\begin{array}{l}\text { Kamu sağlığını tehdit eden çevresel } \\
\text { tehlikeler abartıdan ibarettir. }\end{array}$ & 0,836 & 4,30 & 1,34 & & & \\
\hline
\end{tabular}

Toplam ortalama: 4,38

Toplam Açıklanan Varyans: \%66

Değerlerle başlayan nedensel zincirin sonraki aşamasında, bireysel değerlerle katılımcıların yeni ekolojik dünya görüşleri arasındaki ilişkiye bakılmıştır $(r=0,42 ; \beta=0,56 ; p<0,01)$. Elde edilen korelasyon katsayısı, pozitif bir ilişki olduğunu göstermektedir (Steg vd. 2005). Veriler, katılımcıların alturistik ve biyosferik değer yargılarının, toplam bireysel değerleri üzerinde ve yeni ekolojik dünya görüşlerinin motive edilmesinde olumlu etkiye sahip olduğunu göstermektedir. Bu da kurulan $\mathrm{H}_{2}, \mathrm{H}_{3}$ ve $\mathrm{H}_{4}$ hipotezlerinin doğruluğunu kanitlamaktadır.

DINN Teorisi'ne göre, bireyin çevresel duyarlılık davranışları ölçülürken inanç boyutunda yer alan üç değişkenin etkisine ve ilişki gücüne bakılması gereklidir. Han vd. (2017), müşterilerin, çevresel sorumluluklarını üstlenmeye hazır olmalarında ve farkındalık düzeylerinde, yeni ekolojik dünya görüşlerinin olumlu etkisi olduğunu saptamışlardır. Müşterilerin çevresel inançları- nın bu iki boyutu, çevre yanlısı karar verme sürecinde motive edici etkenler olarak belirtilmiştir. Bu doğrultuda bu araştırmada katılımcıların yeni ekolojik dünya görüşleriyle çevresel sorunların farkındalık boyutları arasındaki ilişkiye bakılmış ve anlamlı pozitif bir ilişki olduğu saptanmıştır $(r=0,54, \beta=0,62 ; p<0,01)$. Katılımcıların yeni ekolojik dünya görüşleri çevre yanlısı olduğundan, çevre sorunlarıyla ilgili farkındalık düzeyleri de artış göstermiş ve $\mathrm{H}_{5}$ hipotezi de kabul görmüştür.

Araştırmanın nedensel zincirinde, çevresel sorunların farkındalığından, atfedilen çevresel sorumlulukların üstlenilmesine giden yolda da pozitif ilişki $(r=0,22 ; \beta=0,41 ; p<0,01)$ bulunmuştur. $\mathrm{Bu}$ değerler, istatistiksel anlamda H6 hipotezinin kabul edilmesini sağlasa da söz konusu iki değişken arasındaki ilişki puanı düşük çıkmıştır. Çevresel sorunların farkında olunması durumunda bireylerin, söz konusu sorunun giderilmesi ve 
Feriyal Farhadi Andarabi - Azize Hassan

Tablo 4. Katılımcıların Çevresel Sorumluluklarını Üstlenmeye Hazır Olma Puanları (n=265)

\begin{tabular}{|c|c|c|c|c|c|}
\hline Madde & $\begin{array}{l}\text { Faktör } \\
\text { Yükü }\end{array}$ & Ortalama & SS & $\begin{array}{l}\text { Cronbach } \\
\text { Alfa }\end{array}$ & Özdeğer \\
\hline $\begin{array}{l}\text { Meydana gelen çevresel sorunlardan kendimi müşterek } \\
\text { sorumlu olarak görüyorum. }\end{array}$ & 0,882 & 3,45 & 1,30 & \multirow{6}{*}{0,816} & \multirow{6}{*}{3,654} \\
\hline $\begin{array}{l}\text { Doğal kaynakların tükenmesinden kendimi müşterek sorumlu } \\
\text { olarak görüyorum. }\end{array}$ & 0,860 & 3,47 & 1,24 & & \\
\hline $\begin{array}{l}\text { Küresel ısınma ve sorunlarından kendimi müşterek sorumlu } \\
\text { olarak görüyorum. }\end{array}$ & 0,864 & 3,45 & 1,25 & & \\
\hline Çevre sorunlarının çözülmesine destek sağlıyorum. & 0,876 & 2,32 & 1,18 & & \\
\hline $\begin{array}{l}\text { Çevre sorunlarının çözülmesinden yalnızca hükümet, resmî } \\
\text { makamlar ve sanayi sorumlu değildir; bireylerin de } \\
\text { yükümlülükleri vardır. }\end{array}$ & 0,878 & 2,07 & 1,20 & & \\
\hline $\begin{array}{l}\text { Bireyler ilke olarak çevre sorunlarının azaltılmasına katkıda } \\
\text { bulunabilirler. }\end{array}$ & 0,890 & 2,13 & 1,27 & & \\
\hline
\end{tabular}

Toplam Ortalama: 2,81

Toplam Açıklanan Varyans: $\% 70$

Tablo 5. Katılımcıların Çevresel Norm Puanları $(\mathrm{n}=265)$

\begin{tabular}{|c|c|c|c|c|c|}
\hline Madde & $\begin{array}{l}\text { Faktör } \\
\text { Yükü }\end{array}$ & Ortalama & SS & $\begin{array}{l}\text { Cronbach } \\
\text { Alfa }\end{array}$ & Özdeğer \\
\hline $\begin{array}{l}\text { Çalıştığım işletme çevreye duyarlı bir işletme ise ve çevre } \\
\text { dostu ürünler ve hizmetler sunuluyorsa, kendimi daha iyi } \\
\text { hissederim. }\end{array}$ & 0,822 & 3,34 & 1,09 & \multirow{10}{*}{0,820} & \multirow{10}{*}{4,954} \\
\hline $\begin{array}{l}\text { Normal işletme yerine çevreye duyarlı işletmede çalışmak } \\
\text { için kendimi ahlaken zorunlu hissediyorum. }\end{array}$ & 0,845 & 3,15 & 1,04 & & \\
\hline $\begin{array}{l}\text { Benim gibi insanlar çevreyi korumak için ellerinden geleni } \\
\text { yapmalıdırlar. }\end{array}$ & 0,836 & 3,10 & 1,01 & & \\
\hline $\begin{array}{l}\text { İşletmede çalışırken çevreyi ve doğayı dikkate alma } \\
\text { konusunda kendimi zorunlu hissediyorum. }\end{array}$ & 0,864 & 3,05 & 1,01 & & \\
\hline $\begin{array}{l}\text { Diğerleri ne yaparsa yapsın, çevreye duyarlı işletmede } \\
\text { çalışmayı ahlaken zorunluluk olarak görüyorum. }\end{array}$ & 0,810 & 3,04 & 1,09 & & \\
\hline $\begin{array}{l}\text { Enerji tasarrufuna katkıda bulunmayı kişisel zorunluluk } \\
\text { olarak görüyorum. }\end{array}$ & 0,870 & 3,01 & 1,03 & & \\
\hline $\begin{array}{l}\text { Su tasarrufuna katkıda bulunmayı kişisel zorunluluk olarak } \\
\text { görüyorum. }\end{array}$ & 0,868 & 3,03 & 1,12 & & \\
\hline $\begin{array}{l}\text { Atık kontrolüne katkıda bulunmayı kişisel zorunluluk } \\
\text { olarak görüyorum. }\end{array}$ & 0,865 & 3,05 & 1,08 & & \\
\hline $\begin{array}{l}\text { Hava kirliliğini önlemek için katkıda bulunmayı kişisel } \\
\text { zorunluluk olarak görüyorum. }\end{array}$ & 0,856 & 3,02 & 1,10 & & \\
\hline $\begin{array}{l}\text { Çevre ve içindekileri (canlılar, kaynaklar vb.) korumadığım } \\
\text { zaman kendimi suçlu hissediyorum. }\end{array}$ & 0,842 & 4,05 & 1,00 & & \\
\hline \multicolumn{6}{|l|}{ Toplam Ortalama: 3,18} \\
\hline Toplam Açıklanan Varyans: \%72 & & & & & \\
\hline
\end{tabular}




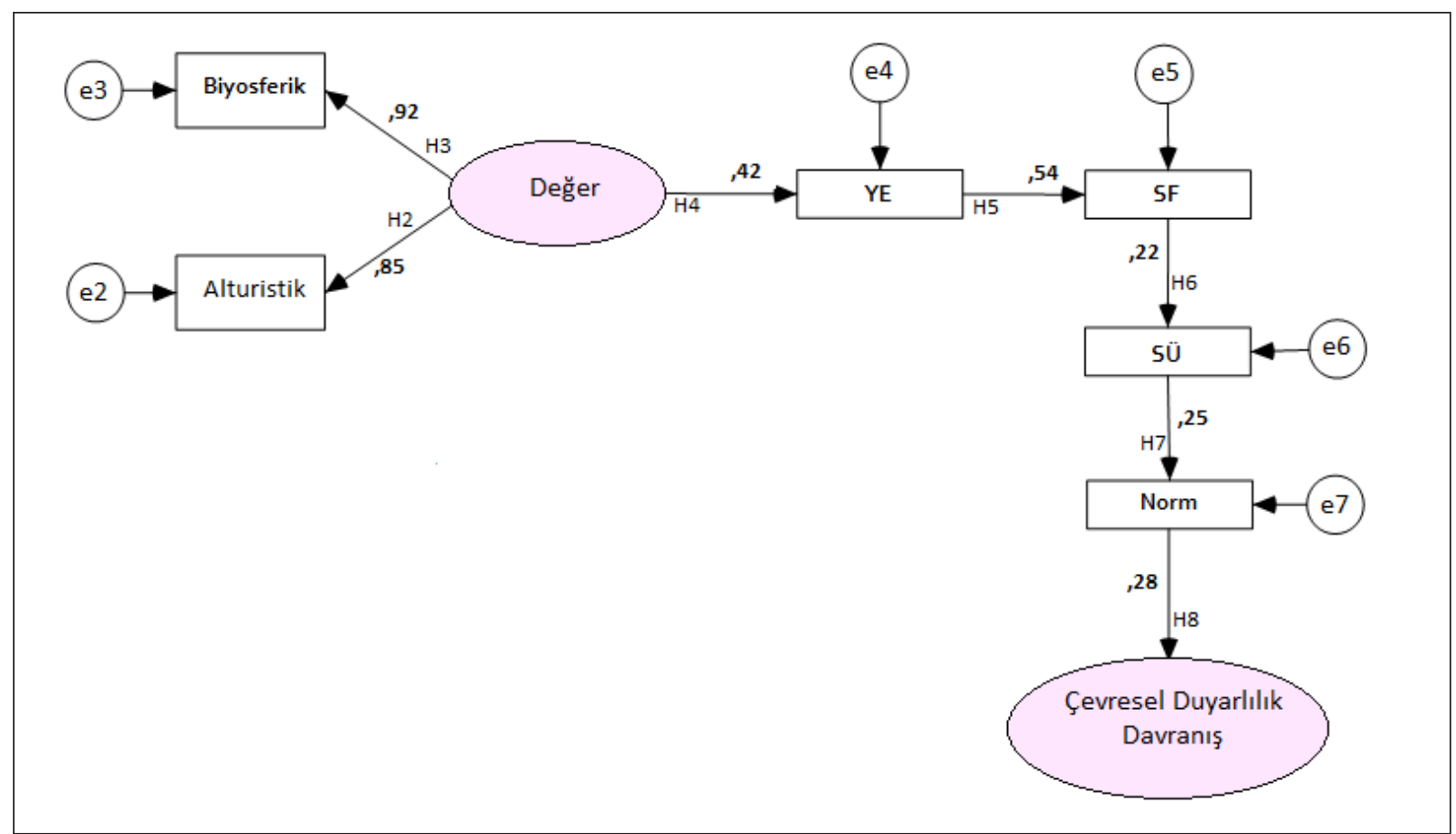

(YE=Yeni Ekolojik Dünya Görüşü, SF=Sorunlarnn Farkındalığı, SÜ=Sorumluluğun Üstlenilmesi)

Şekil 1. Din Teorisi Nedensel Zincirinin Yol Diyagramı ve Standartlaştııılmış Katsayıları ( $\mathrm{n}=265)$

çözülmesi için kendilerine düşen sorumlulukları üstlenmeleri gerekmektedir. Oysa bu araştırmada katılımcıların, çevre sorunları ve oluşan sonuçlar hakkındaki farkındalık duyguları güçlü olmasına rağmen, atfedilen sorumlulukları üstlenmekten kaçındıkları görülmektedir.

Schwartz (1977; 1992) Temel Değer Teorisi'nde, evrensel düşünen, değişime hazır ve sorumluluklarını üstlenen bireylerin çevreye duyarlı proaktif davranışlarda bulunduklarını açıklamıştır. Daha sonra DINN teorisyenleri, çevre sorunlarıla ilgili sorumlulukları üstlenmeye hazır bireylerin çevresel normlarını harekete geçirmede başarı11 olacaklarını savunmuşlar ve iki değişken arasında ilişki kurmuşlardır. Bu araştırmada hesaplanan yol katsayısının puanı $(r=0,25 ; \beta=0,42$; $\mathrm{p}<0,01)$, söz konusu ilişkinin varlığını kanıtlamış ve $\mathrm{H}_{7}$ hipotezi istatistiksel olarak kabul görmüş ancak katsayının düşük puanı söz konusu ilişkinin zayıflığını ortaya çıkarmıştır. Raymond vd.nin (2011) araştırma sonucunu bu araştırmadan farklı kılan, söz konusu iki değişken arasında yüksek düzeyde bulunan ilişki puanıdır.

Araştırmanın son aşamasında, katılımcıların çevresel normlarından çevresel duyarlılık davra- nışlarına giden yol diyagramındaki pozitif ilişki de $(r=0,28 ; \beta=0,50 ; p<0,01) H_{8}$ hipotezinin kabul görmesini sağlamıştır. Ancak düşük korelasyon puanı, ilişkinin zayıf olduğunu göstermektedir. Ayrıca katılımcıların, toplam ortalama çevresel duyarlılık norm puanları, çevresel duyarlılık davranışlarına yönelim düzeylerini de ortaya koymaktadir.

\section{SONUÇ VE ÖNERILER}

İklim değişikliğinden kaynaklı sorunların çözümü için bireylerin çevresel duyarlılık davranışlarının öngörülmesine ve üzerinden stratejiler geliştirilmesine yönelik araştırmaların yapılması özellikle son yıllarda ivme kazanmıştır. Turizm alanyazınında, bu konuda yapılan araştırmalarda DİN Teorisi kullanılırken bazılarında özellikle Planlı Davranış Teorisi'yle entegre edildiği saptanmıştır. Ancak bir bütün olarak bakıldı̆̆ında, DİN Teori'sinin nedensel zincirinde yer alan beş değişkenin bireylerde çevresel duyarlılık davranışlarına yön verdiği ve bu değişkenlere odaklanılması gerektiği sonucuna varılmıştır. 
DİN Teorisi'ne uyarlanan bu araştırmada, egoistik değer yargısı dışında nedensel zincirde yer alan tüm değişkenler arasında ilişki bulunduğu saptanmış ve seçilen örneklemde geçerliği teyit edilmiştir. Katılımcıların bireysel değerleri ve yeni ekolojik dünya görüşleri orta düzeyde bir puana karşılık gelirken çevresel sorunların farkındalığına ait puan nispeten yüksek çıkmıştır. Bunun nedenini Choi vd. (2015), biyosferik değer yargılarıyla çevresel sorunların farkındalığ sındaki olumlu etkileşime bağlamışlardır. Araştırmada en çok dikkat çeken sonuç, sorumluluk üstlenmeye hazır olma değişkenine ait ortalama puanın düşük çıkmasıdır. Katılımcıların, ortalamanın üstünde bir puanla çevresel sorunların farkında oldukları görülse de bu konuda üstlenmeleri gereken sorumluluklardan kaçındıkları görülmektedir. Youn vd. (2020), sorumluluk üstlenme duygusunun, ahlaki yükümlülüklerin yerine getirilmesinde ve dolayısıyla davranışlara yansımasında olumlu etkisi olduğunu açıklamışlardır. Bu araştırmada da değişkenler arası korelasyon puanları incelendiğinde benzer sonuca ulaşılmış ve en düşük puanın, çevresel sorunların farkındalığı ile atfedilen çevresel sorumlulukların üstlenilmesi arasındaki yolda olduğu görülmüştür. Her ne kadar katılımcıların çevresel normları, bu zayıf ilişkiyi güçlendirmek için devreye girip durumu hafifletse de çevresel duyarlılık davranışlarına giden yoldaki düşük korelasyon katsayısı bu olumsuz etkiye yansımaktadır. Psikoloji bilimi insana, çok yönlü ve belirli kalıplara sığmayan bir varlık olarak yaklaşmayı tavsiye etmektedir. DIN Teorisi de teorisyenleri tarafından, insanın psikososyal yapısı dikkate alınarak oluşturulduğu için nedensel zincirinde birçok psikolojik etkeni barındırmaktadır. Anket sorularına verilen bazı cevapların abartılı olduğu, yüz yüze görüşmelerde anlaşılmış olsa da DİN Teorisi, çevresel duyarlılık konusunda gerçek ve yerleşik bakış açılarını ortaya çıkarmaktadır. Katılımcıların çevresel duyarlılık davranışlarının, teknolojik ve bilimsel bilgiden çok, doğaya ve varlıklarına karşı hissettikleriyle ve değerleriyle biçimlendiği söylenebilir.

Yavaş şehirlerde gerçekleşen turizm faaliyetlerinin ekonomik boyutta yerel halka destek vermesi, çevresel krizlere göz yumma anlamına gel- memelidir. Katılımcıların özellikle çevresel sorumlulukları üstlenmede gösterdikleri orta düzeydeki performans, bu şehirlerin yerel yönetimlerine ve Yavaş Şehir Birliğine bir uyarı niteliğindedir. Özellikle yöneticilerin, çevre sorunlarının farkında oldukları hâlde sorumluluk üstlenmeme eğilimleri ayrı bir araştırma konusudur. Bu durumun nedenlerinin araştırılması ve sorunların gerçek anlamda ortadan kaldırılabilmesi için devletin, akademisyenlerin, sektör temsilcilerinin, yerel yönetimlerin ve sivil toplum kuruluşlarının iş birliği yapması önerilmektedir. Yöneticilerin çevresel sorumluluk üstlenme bilincinin gelişmesi için ayrıca ve kapsamlı eğitimler almaları gereklidir. Bunun için yavaş şehir belediyelerinin, Kültür ve Turizm Bakanlığ ve alanında uzman akademisyenlerle iş birliği yaparak, konaklama işletmesi yöneticilerinin, mevcut değerler yönelimlerini göz önünde bulundurarak çevre konusunda davranış değişikliğine yön verebilecek; değerlerden kaynaklanan ahlaki yükümlülüklerini güdüleyebilecek ve geliştirebilecek eğitim programları düzenleyip, katılımı zorunlu tutmalarının faydalı olacağı öngörülmektedir.

Turizm alanında 2021 yılı Ekim ayına kadar taranan ulusal ve uluslararası indeksli dergilerde yayınlanan makalelerde ve Yükseköğretim Kurulu Ulusal Tez Merkezinde konaklama işletmesi yöneticilerinin çevresel duyarlılık davranışlarına DINN Teorisi açısından yaklaşan araştırmaya rastlanmamıştır. Bu araştırmada, DİN Teorisi temelinde, konaklama işletmesi yöneticilerinin bireysel değerleri, çevresel duyarlılık inançları ve normları incelenerek bu değişkenlerin önemli rolleri ve birbirleriyle ilişkileri sosyal psikolojik açıdan tartışılmış ve kavramsal temelleri açıklanmıştır. Dolayısıyla araştırmanın, konaklama işletmesi yöneticilerinin çevresel duyarlılık davranışları bağlamında alanyazının gelişmesine fayda sağlayacağı düşünülmektedir.

$\mathrm{Bu}$ araştırma, toplumlarda kültürel ve psikolojik farklılıkların önemi dikkate alınarak, yüksek maliyetlere rağmen, Türkiye sınırları içinde Cittaslow Birliği üyesi 18 yavaş şehrinde faaliyet gösteren konaklama işletmesi yöneticilerine yönelik olarak yapılmıştır. Bundan sonra yapılacak çalışmalarda bu konu, uluslararası boyuta taşı- 
nabilir ve diğer ülkelerdeki yavaş şehirlerde faaliyet gösteren konaklama işletmesi yöneticileri üzerinde araştırma yapılabilir.

Zaman boyutu açısından, bu araştırmadaki sonuçlar, 2018 ve 2019 yıllarında toplanan verilere dayanılarak elde edilmiştir. Bundan sonraki süreçte yavaş şehirlerdeki konaklama işletmesi yöneticilerinin bireysel değerlerinde, çevresel duyarlılık inançları ve normlarında değişiklik olup olmadığı hakkında bilgiye ulaşmak için yeni bir araştırma yapılabilir. Ayrıca eğer değişiklik varsa hangi boyutların etkilendiğinin belirlenmesi gerekir. Bu şekilde, 2023'e kadar elde edilen yeni verilerin değerlendirilmesinin, Türkiye'nin Turizm Stratejisi 2023 Eylem Planı'nda yer alan hedeflere ulaşılmasındaki başarı düzeyinin artmasına katkı sağlayacağı öngörülmektedir.

Kuşkusuz günümüzde, sadece kamu kurumlarının ve özel sektör kuruluşlarının sosyal sorumluluk kapsaminda çevresel duyarlılık projeleri ve kampanyalar yürütmesi yeterli değildir. Dünyada yaşayan her bir birey, kendisi için çevreyi koruması gerektiği gerçeğini kavramalı ve çevresel vatandaşlık görevlerini yerine getirmelidir. Yavaş şehirlerdeki konaklama işletmesini yöneten bireyler, zaman içinde, yavaş şehir statüsünde olmayan bir şehirde de aynı işi yapabilirler. Bu nedenle, konaklama işletmesi yöneticilerinin, çevresel vatandaşlığın bir görev olduğunu kabul ederek bunun gereklerini yerine getirmeleri beklenmektedir.

\section{KAYNAKÇA}

Bohdanowicz, P. ve Zientara, P. (2014). Environmental Performance Assessment Systems in THA Hotel Industry, International Business and Global Economy, 33: 743-755.

Browne, M. W. ve Cudeck, R. (1993). Alternative Ways of Assessing Model Fit. İçinde Bollen, K.; Long, J., (Editörler), Testing Structural Equation Models, (ss.136-162), CA: Sage.

Büyüköztürk, Ş. (2011). Sosyal Bilimler için Veri Analizi El Kitabı. Ankara: Pegem Akademi Yayıncılık.

Chaney, D. ve Martin, D. (2017). The Role of Shared Values in Understanding Loyalty Over Time: a Longitudinal Study on Music Festivals, Journal of Travel Research, 56 (4): 507-520.

Choi, H. M., Kim, W. G., Kim, Y. J. ve Agmapisarn, C. (2019). Hotel Environmental Management Initiative (HEMI) Scale Development, International Journal of Hospitality Management, 77: 562-572.
Choi, H., Jangb, J. ve Kandampully, J. (2015). Application of the Extended VBN Theory to Understand Consumers' Decisions about Green Hotels, International Journal of Hospitality Management, 51: 87-95.

Cittaslow International. (2020). Association, https://www.cittaslow.org/content/association, Erişim tarihi: 23 Kasım 2020.

Dietz, T., Fitzgerald, A. ve Shwom, R. (2005). Environmental Value, Annual Review of Environment and Resources, 30: 335-372.

Dietz. T. (2020). Yayınlanmamış el notları.

Dunlap, R. E., Van Liere, K. D., Mertig, A. G. ve Jones, R. E. (2000). Measuring Endorsement of the New Ecological Paradigm: A Revised NEP Scale, Journal of Social Issues, 56 (3): 425-442.

Han, H. (2015). Travelers' Pro-Environmental Behavior in a Green Lodging Context: Converging Value-BeliefNorm Theory and the Theory of Planned Behavior, Tourism Management, 47: 164-177.

Han, H., Hwang, J. ve Lee, M. J. (2017). The Value-BeliefEmotion-Norm Model: Investigating Customers' EcoFriendly Behavior, Journal of Travel and Tourism Marketing, 34 (5): 590-607.

Han, H., Olya, H. G. T., Cho, S. ve Kim, W. (2018). Understanding Museum Vacationers' Eco-Friendly DecisionMaking Process: Strengthening the VBN Framework, Journal of Sustainable Tourism, 26 (6): 855-872.

Kim, W.G., Li, J., Han, J. S. ve Kim, Y. (2017). The Influence of Recent Hotel Amenities and Green Practices on Guests' Price Premium and Revisit Intention, Tourism Economics, 23 (3): 577-593.

Landon, A. C., Woosnam, K. M. ve Boley, B.B. (2018). Modeling the Psychological Antecedents to Tourists' ProSustainable Behaviors: an Application of the ValueBelief-Norm Model, Journal of Sustainable Tourism, 26 (6): 957-972.

Megeirhi, H. A., Woosnam, K. M., Ribeiro, M.A., Ramkissoon, H. ve Denley, T.J. (2020). Employing a Value-BeliefNorm Framework to Gauge Carthage Residents' Intentions to Support Sustainable Cultural Heritage Tourism, Journal of Sustainable Tourism, 28 (9): 1351-1370.

O'Neill, D. W., Fanning, A. L., Lamb, W.F. ve Steinberger, J. K. (2018). A Good Life for all within Planetary Boundaries, Nature Sustainability, 1: 88-95.

Olya, H. G. T. ve Akhshik, A. (2019). Tackling the Complexity of the Pro-environmental Behavior Intentions of Visitors to Turtle Sites, Journal of Travel Research, 58 (2): 313-332.

Raymond, C., Brown, G. ve Robinson, G. (2011). The Influence of Place Attachment and Moral Normative Concerns on The Conservation of Native Vegetation: a Test of Two Behavioral Models, Journal of Environmental Psychology, 31: 323-335.

Schwartz, S. H. (1977). Normative Influence on Altruism. İçinde L. Berkowitz (Editör), Advances in Experimental Social Psychology, (ss. 221-279), New York: Academic Press.

Schwartz, S. H. (1992). Universals in the Content and Structure of Values: Theoretical Advances and Empirical Tests in 20 Countries, Advances in Experimental Social Psycho$\log y, 25: 1-65$. 
Steg, L., Dreijerink, L. ve Abrahamse, W. (2005). Factors Influencing the Acceptability of Energy Policies: A Test of VBN Theory, Journal of Environmental Psychology, 25 (4): 415-425.

Stern, P.C., Dietz, T. ve Kalof, L. (1993). Value Orientations, Gender, and Environmental Concern, Environment and Behavior, 25 (3): 322-348.

Stern, P. C. ve Dietz, T. (1994). The Values Basis of Environmental Concern, Journal of Social Issues, 50 (3): 65-84.

Stern, P. C., Dietz, T., Abel, T., Guagnano, G. A. ve Kalof, L. (1999). A Value-Belief-Norm Theory of Support for Social Movements: The Case of Environmental Concern, Human Ecology Review, 6 (2): 81-97.
Stern, P. C. (2000). Toward a Coherent Theory of Environmentally Signifficant Behavior, Journal of Social Issues, 56 (3): 407-424.

Van Der Linden, S. (2015). Intrinsic Motivation and Proenvironmental Behaviour, Nature Climate Change, 5: 612-613.

Van der Werff, E. ve Steg, L. (2016). The Psychology of Participation and Interest in Smart Energy Systems: Comparing the Value-Belief-Norm Theory and the Valueidentity-Personal Norm Model, Energy Research \& Social Science, 22: 107-114.

Youn, H., Yin, R., Kim, J. H. ve Li, J. (2020). Examining Traditional Restaurant Diners' Intention: an Application of the VBN Theory, International Journal of Hospitality Management, 85 (102360): 1-12.
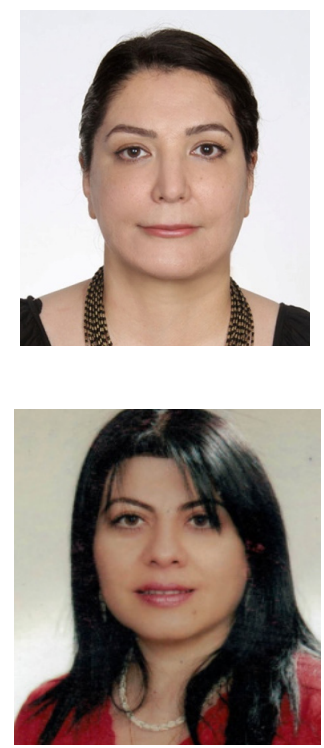

Feriyal FARHADI ANDARABI

Tebriz Üniversitesi Matematik Dalı'nda eğitimini tamamladı. Yüksek lisans derecesini Gazi Üniversitesi'nden Turizm İşletmeciliği Dalı'nda aldı (2012). Gazi Üniversitesi'nde Turizm İşletmeciliği Dalı'nda doktora eğitimine devam etmektedir. Bilimsel ve sanatsal bakışın harmanlanmasıyla, turizm alanında araştırmalarını yürütmeyi tercih etmektedir. Temel çalışma alanları; cittaslow, çevre yönetimi, sürdürülebilirlik, gastronomi ve el sanatlarıdır.

\section{Azize HASSAN}

Gazi Üniversitesi Mesleki Eğitim Fakültesi Turizm İşletmeciliği ve Otelcilik Eğitimi Bölümü’nden mezun oldu (1985). Yüksek lisans derecesini Gazi Üniversitesi Sosyal Bilimler Enstitüsü Üretim Yönetimi ve Pazarlama Programı'ndan (1989), doktora derecesini de İstanbul Üniversitesi Sosyal Bilimler Enstitüsü Turizm Programı́ndan aldı (1993). Gazi Üniversitesi Mesleki Eğitim Fakültesi Turizm İşletmeciliği ve Otelcilik Eğitimi Bölümü’nde Araştırma Görevlisi olarak çalışmaya başladı (1986). Sonrasında Profesör olarak görevine devam etti (2004). Gazi Üniversitesi'nin bölünmesi ile Ankara Hacı Bayram Veli Üniversitesi, Turizm Fakültesi, Turizm İşletmeciliği Bölümü’nde Profesör olarak görev yapmaktadır (2020-). Temel çalışma alanları; turizm eğitimi, turizm işletmelerinde pazarlamadır. 